\title{
Differential Physiological and Ultrastructural Responses of Cottonseeds under Pb Toxicity
}

\author{
Mumtaz Khan ${ }^{1,2}$, Muhammad Daud Khan ${ }^{1,2 *}$, Basharat Ali', \\ Noor Muhammad ${ }^{2}$, Shui-Jin Zhu ${ }^{1 * *}$ \\ 'Institute of Crop Science, College of Agriculture and Biotechnology, Zhejiang University, Hangzhou, China \\ ${ }^{2}$ Department of Biotechnology and Genetic Engineering, Kohat University of Science and Technology, Pakistan \\ Received: 3 February 2014 \\ Accepted: 28 March 2014
}

\begin{abstract}
Lead $(\mathrm{Pb})$ is a toxic heavy metal that causes physiological and morphological changes in plants. Our current study was aimed at observing $\mathrm{Pb}$-induced changes in seeds of two upland cotton varieties (TM- 1 and Z$747)$ that were exposed for 24 hours to various Pb concentrations $(0,50,100,300$, and $500 \mu \mathrm{M})$. Seeds of TM-1 showed higher germination percentages, water uptake, and cell viability as compared to Z-747. Changes in nuclei shape, their partial disappearance, and increase in vacuole size were the initial signs of lead toxicity in Z-747, while TM-1 maintained its typical conformations. Cell wall thickening; increase in the number of mitochondria, protein, and lipid bodies; and vacuolation were more prominent in TM-1. In contrast, plasmolytic shrinkage and scattered cell organelles were the key characteristics of Z-747 at higher doses of Pb. Those observations demonstrated that seeds of TM-1 were more tolerant to Pb stress as compared to Z-747 and may be considered a preferred choice for culture on $\mathrm{Pb}$-contaminated soils.
\end{abstract}

Keywords: lead stress, physiology, Gossypium hirsutum L. seeds, ultrastructural study

\section{Introduction}

Seed is the start of new life and germination studies help to characterize a specific cultivar under stress conditions [1]. Different environmental factors like drought, temperature, salinity, and heavy metal contamination affect seed germination and ultimate growth of plants [2, 3]. Literature reveals that lead $(\mathrm{Pb})$ is a non-essential toxic heavy metal for plants $[4,5]$. Its main uptake occurs via roots, where it binds to carboxyl groups of mucilage uronic acid or when it comes in direct contact with polysaccharides of rhizodermal cells. But at the molecular level, the exact mechanism remains a matter of discussion [6]. Pb affects various physiological functions of plants like photosynthesis, water uptake, nutrient balance, and germination [4]. It interferes with carbohy-

\footnotetext{
*e-mail: mkdaud@yahoo.com
}

**e-mail:shjzhu@zju.edu.cn drate and protein metabolism in seeds and affects the activities of metabolizing enzymes like amylases, acid invertases, and proteases. Altered activities of these enzymes might negatively affect metabolism of seed reserves needed for radical emergence [7]. Basically, $\mathrm{Pb}$ induces biochemical changes that usually trigger some crosstalk between antioxidant enzymes and reactive oxygen species (ROS), including singlet oxygen and hydrogen peroxide [8]. Although ROS plays a significant role in seed development, germination, dormancy, and aging, their overproduction can cause serious effects on seeds. It is under debate whether an increased level of $\mathrm{Pb}$ could affect the seed embryo as compared to the endosperm or cotyledons [9].

Besides physiological changes, $\mathrm{Pb}$ also causes ultrastructural variations in the cells of different plant parts [10, 11]. From a morphological point of view, chloroplasts and mitochondria represent indispensible components of cellular metal homeostasis in photosynthetic cells [12] and are 
the main targets of abiotic stress [13]. In two species of Lespedeza, ultrastructural analyses indicate an increase in the number and volume of starch grains, low density of cell organelles in cytoplasm, some disintegration of mitochondria, dilation of nuclear envelops, and irregular cell wall thickening [14].

Inside cells, plants have developed various mechanisms for detoxifying $\mathrm{Pb}$ such as sequestration in vacuole, phytochelatin synthesis, and binding to glutathione and amino acids $[15,16]$. The tolerance capacity of plants against $\mathrm{Pb}$ is mainly associated with its restrictive localization to their cell walls, synthesis of osmolytes, and activation of the antioxidant enzyme system [17]. So, better understanding of $\mathrm{Pb}$ tolerance in cotton seeds requires ultrastructural observations in addition to physiological studies.

Seed coats play a key role in delayed germination, and its structural variations control the diffusion chemistry of seeds when comparing seeds with or without coats in growth medium [18]. To standardize the measure of seed reserves mobilization and to compare the sensitivity of cotton cultivars to $\mathrm{Pb}$ stress, seed coats were manually removed in our experimental series. We have focused on seeds of 2 upland cotton germplasms i.e. TM-1 and Z-747 differing in $\mathrm{Pb}$ toxicity based on initial screening of seven varieties (data not shown here). Since most research work previously done in cotton is focused on leaves and roots, when studying metal toxicity $[19,20]$ we tried to explore seed response to elevated levels of $\mathrm{Pb}$. Our main objectives were thus to study physiological behavior as well as ultrastructural changes in seeds of cotton cultivars different in $\mathrm{Pb}$ tolerance. To the best of our knowledge, there is no detailed $\mathrm{Pb}$ toxicity comparative study yet reported in germinating cotton seeds.

\section{Materials and Methods}

\section{Seed Treatment and Growth Conditions}

Two cultivars of upland cotton were used in our experiments i.e. TM-1, a standard genetic line, and Z-747, an extending breeding material suitable for the Xinjiang region of China. Seeds were surface sterilized with $0.1 \%$ (w/v) $\mathrm{HgCl}_{2}$ for 5-6 min, washed thrice with distilled water, and seed coats were removed manually. Eight seeds in each Petri dish were supplied with $10 \mathrm{ml}$ of half strength modified Hoagland solution containing five different levels of $\mathrm{Pb}\left(\mathrm{NO}_{3}\right)_{2}$ i.e. $0,50,100,300$, and $500 \mu \mathrm{M}$. Covered Petri dishes were kept in a growth chamber under dark conditions for 24 hours at $28 \pm 2^{\circ} \mathrm{C}$ with relative humidity of $60 \%$. After 24 hours, germinated seeds were treated with $\mathrm{Na}_{2}$-EDTA for 15-20 min to remove unbound $\mathrm{Pb}$, followed by thorough washing with distilled water. Modified Hoagland solution comprised of $500 \mu \mathrm{M}\left(\mathrm{NaH}_{4}\right)_{2} \mathrm{SO}_{4}, 500 \mu \mathrm{M} \mathrm{MgSO}$, 200 $\mu \mathrm{M} \mathrm{K}_{2} \mathrm{SO}_{4}, 1000 \mu \mathrm{M} \mathrm{KNO}_{3}, 600 \mu \mathrm{M} \mathrm{Ca}\left(\mathrm{NO}_{3}\right)_{2} \cdot 4 \mathrm{H}_{2} \mathrm{O}, 200$ $\mu \mathrm{M}, \mathrm{KH}_{2} \mathrm{PO}_{4}, 10 \mu \mathrm{M} \mathrm{FeSO} \cdot 12 \mathrm{H}_{2} \mathrm{O}, 0.5 \mu \mathrm{M} \mathrm{MnSO} \cdot \mathrm{H}_{2} \mathrm{O}$, $0.25 \mu \mathrm{M} \mathrm{ZnSO} \cdot 7 \mathrm{H}_{2} \mathrm{O}, 0.05 \mu \mathrm{M} \mathrm{CuSO} \cdot 5 \mathrm{H}_{2} \mathrm{O}, 100 \mu \mathrm{M}$ $\mathrm{H}_{3} \mathrm{BO}_{3}$, and $0.02 \mu \mathrm{M}\left(\mathrm{NH}_{4}\right)_{6} \mathrm{Mo}_{7} \mathrm{O}_{24} \cdot 4 \mathrm{H}_{2} \mathrm{O}$, adjusted to $\mathrm{pH}$
6.5. To avoid precipitation of $\mathrm{Pb}\left(\mathrm{NO}_{3}\right), 50 \mu \mathrm{M} \mathrm{Na} \mathrm{Na}_{2}$-EDTA was also added to the nutrient medium.

\section{Physiological Parameters}

After treatment, seeds were first properly blotted dry between tissue papers to remove excess water and changes in seed weight and relative weight increase were carefully noted in both varieties. Water content was determined based on fresh and dry weights using the formula:

$$
W C(\%)=[(F W-D W) / F W] \times 100
$$

For dry weight determination, samples of TM-1 and Z747 were oven dried at $65^{\circ} \mathrm{C}$ for 72 hours.

Cell viability was determined by triphenyl tetrazolium chloride (TTC) reduction method [21]. A standard curve was drawn using a $0.4 \%$ TTC solution, where $(\mathrm{Y}=0.003 \mathrm{X}$ $+0.009), \mathrm{Y}$ represent $=\mathrm{OD} 485$ value, and $\mathrm{X}=\mu \mathrm{g}$ TTF (Tetrazolium triphenyl formazan content).

\section{$\mathrm{Pb}$ Accumulation in Seeds}

For $\mathrm{Pb}$ uptake, seeds of TM-1 and Z-747 were dried to constant weight at $70^{\circ} \mathrm{C}$ for 72 hours, ashed in a muffle furnace at $250^{\circ} \mathrm{C}$ initially for 2 hours, followed by $500^{\circ} \mathrm{C}$ heating for another 10 hours. The ash of each sample was dis-

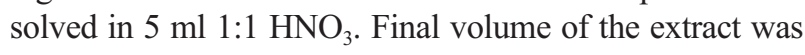
$10 \mathrm{ml}$ with distilled water addition, and each sample was filtered twice to get the clear extract. $\mathrm{Pb}$ content was determined by an inductively coupled plasma mass spectrometer (ICP-MS 7500a, Agilent). Pneumatic nebulization technique was applied using a peristaltic pump with sample uptake@1 $1 \mathrm{ml} \cdot \mathrm{min}^{-1}$. To minimize any memory effects, the system was operated in mass scanning mode, after tuning ion lenses. Each standard, sample, or blank was aspirated for about $2 \mathrm{~min}$ before data acquisition. An appropriate interval time ( $2 \mathrm{~min}$ ) was maintained between the sample and blank. The data were expressed as $\mu \mathrm{g} \cdot \mathrm{g}^{-1}$ dry weight.

\section{Transmission Electron Microscopy}

Small sections of radical base (2-3 $\mathrm{mm}$ in length) of TM-1 and Z-747 were selected for electron microscopy observations. Sections were first fixed in $2.5 \%$ glutaraldehyde (v/v) in 0.1 M BPS (sodium phosphate buffer, $\mathrm{pH} 7.2$ ) for more than 4 hours and then post-fixed in $1 \% \mathrm{OsO}_{4}$ in phosphate buffer (0.1 M, pH 7.2) for 1.5 hours. Specimens were dehydrated with a graded series of ethanol for 15-20 $\min$ i.e. $50 \%, 70 \%, 80 \%, 90 \%, 95 \%$, and $100 \%$, followed by absolute acetone for $20 \mathrm{~min}$. Then specimens were placed in 1:1 mixture of absolute acetone and final spur resin for 1 hour at room temperature and transferred to mixture of absolute acetone and final spur resin (1:3) for 3 hours. Finally, specimens were put in final resin spur a mixture overnight. Ultra thin sections $(90 \mathrm{~nm})$ stained with uranyl acetate and lead citrate, mounted on gold, were examined with a transmission electron microscope (model H-7650 Hitachi, Japan) operating at $60 \mathrm{kV}$. 
Table 1. Germination percentage, inhibitory germination rate, change in weight, and relative percent weight increase (RPWI) of two cotton varieties i.e. TM-1 and Z-747 under Pb stress.

\begin{tabular}{|c|c|c|c|c|c|}
\hline \multirow{2}{*}{$\begin{array}{c}\text { Treatment } \\
\mathrm{Pb}(\mu \mathrm{M})\end{array}$} & \multicolumn{2}{|c|}{ Germination percentage (\%) } & \multicolumn{2}{c|}{ Change in weight $(\mathrm{g})$} & \multirow{2}{*}{ RPWI (\%) TM-1 over } \\
Z & TM-1 & Z-747 & TM-1 & Z-747 & 8 \\
\hline 0 & $86.01 \pm 7.90 \mathrm{a}(0)$ & $93.10 \pm 13.26 \mathrm{a}(0)$ & $112.3 \pm 5.8 \mathrm{a}$ & $104.2 \pm 0.0 \mathrm{~b}$ & 77 \\
\hline 50 & $93.71 \pm 15.07 \mathrm{a}(8.2)$ & $80.88 \pm 15.37 \mathrm{ab}(-15.1)$ & $173.9 \pm 119.2 \mathrm{a}$ & $98.5 \pm 14.3 \mathrm{~b}$ & 41 \\
\hline 100 & $87.26 \pm 12.64 \mathrm{a}(1.4)$ & $87.64 \pm 23.65 \mathrm{ab}(-6.2)$ & $219.4 \pm 161.0 \mathrm{a}$ & $155.9 \pm 18.6 \mathrm{ab}$ & 12 \\
\hline 300 & $83.92 \pm 18.93 \mathrm{a}(-2.5)$ & $63.36 \pm 32.56 \mathrm{ab}(-46.9)$ & $146.9 \pm 93.3 \mathrm{a}$ & $131.5 \pm 31.7 \mathrm{ab}$ & 16 \\
\hline 500 & $71.98 \pm 14.56 \mathrm{a}(-19.5)$ & $48.06 \pm 7.25 \mathrm{~b}(-93.7)$ & $198.7 \pm 122.9 \mathrm{a}$ & $170.8 \pm 60.9 \mathrm{a}$ & 16 \\
\hline
\end{tabular}

Values are the mean of three replications \pm SD. Variants possessing the same letters are not statistically significant at $\mathrm{P}<0.05$.

Parenthesis contain inhibitory germination rate.

Table 2. Seed biomass and water content of two cotton varieties, i.e. TM-1 and Z-747 as affected by elevated levels of Pb.

\begin{tabular}{|c|c|c|c|c|c|c|}
\hline \multirow{2}{*}{$\begin{array}{c}\text { Treatment } \\
\mathrm{Pb}(\mu \mathrm{M})\end{array}$} & \multicolumn{2}{|c|}{ Fresh Weight $(\mathrm{g})$} & \multicolumn{2}{c|}{ Dry Weight $(\mathrm{g})$} & \multicolumn{2}{c|}{ Water content $(\mathrm{g})$} \\
\cline { 2 - 7 } & TM-1 & Z-747 & TM-1 & Z-747 & TM- 1 & Z-747 \\
\hline 0 & $1.09 \pm 0.07 \mathrm{a}$ & $0.77 \pm 0.06 \mathrm{a}$ & $0.35 \pm 0.05 \mathrm{ab}$ & $0.24 \pm 0.02 \mathrm{a}$ & $0.65 \pm 0.04 \mathrm{~b}$ & $0.53 \pm 0.04 \mathrm{a}$ \\
\hline 50 & $1.03 \pm 0.05 \mathrm{a}$ & $0.72 \pm 0.07 \mathrm{a}$ & $0.34 \pm 0.03 \mathrm{ab}$ & $0.25 \pm 0.04 \mathrm{a}$ & $0.71 \pm 0.01 \mathrm{ab}$ & $0.51 \pm 0.06 \mathrm{a}$ \\
\hline 100 & $1.10 \pm 0.06 \mathrm{a}$ & $0.71 \pm 0.06 \mathrm{a}$ & $0.36 \pm 0.01 \mathrm{a}$ & $0.24 \pm 0.01 \mathrm{a}$ & $0.72 \pm 0.05 \mathrm{a}$ & $0.50 \pm 0.05 \mathrm{a}$ \\
\hline 300 & $1.03 \pm 0.03 \mathrm{a}$ & $0.79 \pm 0.01 \mathrm{a}$ & $0.38 \pm 0.03 \mathrm{a}$ & $0.23 \pm 0.00 \mathrm{a}$ & $0.67 \pm 0.01 \mathrm{~b}$ & $0.52 \pm 0.01 \mathrm{a}$ \\
\hline 500 & $0.90 \pm 0.01 \mathrm{~b}$ & $0.80 \pm 0.02 \mathrm{a}$ & $0.29 \pm 0.04 \mathrm{~b}$ & $0.22 \pm 0.01 \mathrm{a}$ & $0.58 \pm 0.04 \mathrm{c}$ & $0.53 \pm 0.00 \mathrm{a}$ \\
\hline
\end{tabular}

Values are the mean of three replications \pm SD. Variants possessing the same letters are not statistically significant at $\mathrm{P}<0.05$.

Data obtained from the experiments were subjected to one-way analysis of variance (ANOVA) using a statistical software DPS (data processing system). The significant difference among different treatment means was determined by LSD method.

\section{Results}

\section{Effects of $\mathrm{Pb}$ on Germination and Quantitative Traits}

Radical appearance of $1 \mathrm{~mm}$ length was set as a benchmark for germination rate. Data revealed non-significant changes in TM-1 germination rate while Z-747 showed radical inhibition at elevated $\mathrm{Pb}$ levels as compared to control (Table 1). Comparative analysis demonstrated 50\% more germination in TM-1 vs. Z-747 at $500 \mu \mathrm{M}$. Similarly, at the highest $\mathrm{Pb}$ level, $19.5 \%$ and $93.7 \%$ inhibitory rates were observed in TM-1 and Z-747, respectively, over their respective controls.

Various quantitative traits such as change in weight, fresh and dry weight, as well as water content percentage were also studied. Results showed non-significant changes in seeds' weight of TM-1 at all levels of treatment (Table 1). However, TM-1 absorbed 8\%, 77\%, 41\%, 12\%, and 16\% more water as compared to Z-747 at $0,50,100,300$, and $500 \mu \mathrm{M}$ of $\mathrm{Pb}$, respectively. Although fresh and dry weights of TM-1 and Z-747 were not affected by $\mathrm{Pb}$ but values were higher in TM-1 than Z-747, in all treatments (Table 2).

\section{Effects of $\mathrm{Pb}$ on Cell Viability and Its uptake}

Elevated levels of $\mathrm{Pb}$ induced changes in cell viability of TM-1 and Z-747, as TTC reducing capacity (Table 3). A stimulatory effect on cell viability of TM-1 was found at 50 and $100 \mu \mathrm{M}$, but a $31 \%$ decline was observed at $300 \mu \mathrm{M} \mathrm{Pb}$ over control. However, consecutive decline in viable cells was seen in variety Z-747. A comparison revealed $16 \%$, $63 \%, 89 \%, 1 \%$, and $110 \%$ more viability in TM- 1 as compared to Z-747 at $0,50,100,300$, and $500 \mu \mathrm{M} \mathrm{Pb}$, respectively.

$\mathrm{Pb}$ accumulation in both varieties followed a gradual increase as its concentration increased in growth medium, except in Z-747 at $500 \mu \mathrm{M} \mathrm{Pb}$ (Table 3). Maximum $\mathrm{Pb}$ uptake in TM-1 (4.3 $\left.\mu \mathrm{g} \cdot \mathrm{g}^{-1} \mathrm{Fw}\right)$ and Z-747 (3.7 $\left.\mu \mathrm{g} \cdot \mathrm{g}^{-1} \mathrm{Fw}\right)$ were observed at 500 and $300 \mu \mathrm{M} \mathrm{Pb}$, respectively. Taken together, TM-1 absorbed 3-fold more $\mathrm{Pb}$ than Z-747 at the highest concentration of $\mathrm{Pb}$.

\section{Ultrastructural Observations}

Microscopic observations of controls in both varieties revealed well-developed cell architecture. Intact cell membrane and cell wall, number of mitochondria, large vacuole, well-shaped nuclei and nuclear membranes, and one or 
Table 3. Cell viability as TTF $\left(\mu \mathrm{g} \cdot \mathrm{g}^{-1} \mathrm{Fw}\right)$ and $\mathrm{Pb}$ content $\left(\mu \mathrm{g} \cdot \mathrm{g}^{-1} \mathrm{DW}\right)$ of two cotton varieties, i.e. TM-1 and Z-747, as affected by different levels of $\mathrm{Pb}$.

\begin{tabular}{|c|c|c|c|c|}
\hline \multirow{2}{*}{$\begin{array}{l}\text { Treatment } \\
\mathrm{Pb}(\mu \mathrm{M})\end{array}$} & \multicolumn{2}{|c|}{ Cell viability } & \multicolumn{2}{|c|}{$\mathrm{Pb}$ content } \\
\hline & TM-1 & Z-747 & TM-1 & $\mathrm{Z}-747$ \\
\hline 0 & $117.30 \pm 27.80 \mathrm{abc}$ & $101.43 \pm 42.91 \mathrm{a}$ & $0.292 \pm 0.03 \mathrm{~d}$ & $0.403 \pm 0.21 \mathrm{e}$ \\
\hline 50 & $137.89 \pm 7.75 \mathrm{ab}$ & $83.72 \pm 2.96 \mathrm{ab}$ & $0.719 \pm 0.13 \mathrm{~d}$ & $0.685 \pm 0.21 d$ \\
\hline 100 & $143.00 \pm 25.52 \mathrm{a}$ & $75.19 \pm 9.12 \mathrm{abc}$ & $1.408 \pm 0.04 \mathrm{c}$ & $3.134 \pm 0.20 \mathrm{~b}$ \\
\hline 300 & $89.25 \pm 16.61 \mathrm{c}$ & $63.05 \pm 17.23 \mathrm{bc}$ & $3.238 \pm 0.20 \mathrm{~b}$ & $3.703 \pm 0.12 \mathrm{a}$ \\
\hline 500 & $97.03 \pm 15.57 \mathrm{bc}$ & $45.42 \pm 10.66 \mathrm{c}$ & $4.305 \pm 0.70 \mathrm{a}$ & $1.425 \pm 0.09 \mathrm{c}$ \\
\hline
\end{tabular}

Values are the mean of three replication \pm SD. Variants possessing the same letters are not statistically significant at $\mathrm{P}<0.05$.

more nucleoli were found in microscopic images. Smooth and rough endoplasmic reticulum with attached ribosomes, protein and lipid bodies were also seen throughout the cytoplasm (Figs. 1 A-B). However, cytoplasm appeared denser in TM-1 as compared to Z-747, probably due to lipid and protein bodies' assembly (Fig. 1 A). Vacuolization was more pronounced in Z-747, with the presence of small and larger size vacuoles surrounded by tonoplast membranes. Membrane-bound peroxisomes could also be seen in Z-747 control cells (Fig. $1 \mathrm{~B}$ ).

The detrimental effects of $\mathrm{Pb}$ started at $50 \mu \mathrm{M} \mathrm{Pb}$, when conformational changes appeared in the shape of nuclei, accompanied by the disappearance of nucleoli and an increase in the size of vacuoles of Z-747 (Figs. 1 C-D).
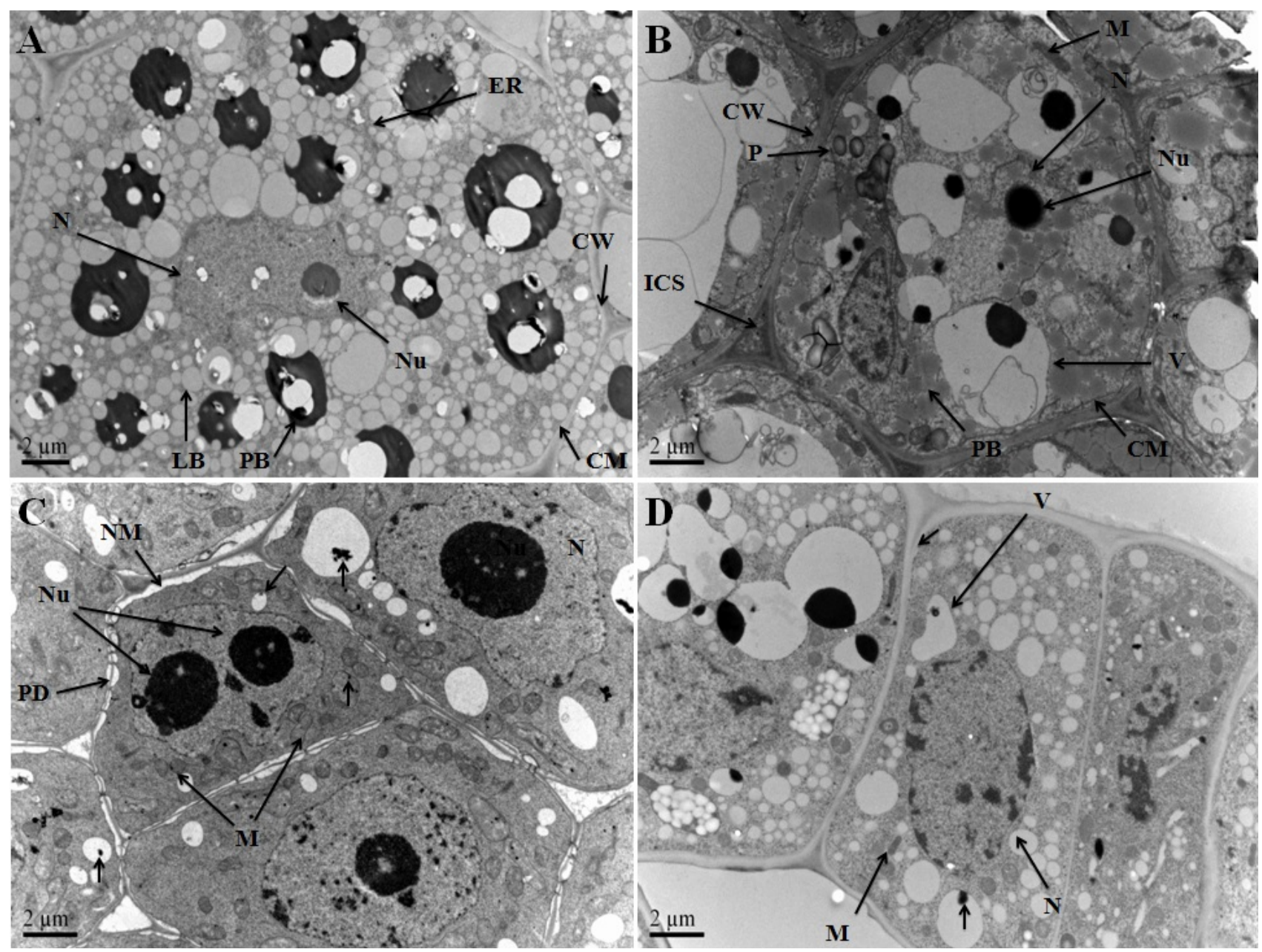

Fig. 1. (A, B) TM-1 and Z-747 at $0 \mu \mathrm{M} \mathrm{Pb}(\mathrm{C}, \mathrm{D}) \mathrm{TM}-1$ and Z-747 at $50 \mu \mathrm{M}$ Pb. Electron micrographs of radical base cells of two upland cotton TM-1 and Z-747 showing nucleus $(\mathrm{N})$, nucleolus $(\mathrm{Nu})$, nuclear membrane $(\mathrm{NM})$, mitochondria (M), endoplasmic reticulum (ER), cell wall $(\mathrm{CW})$, vacuole $(\mathrm{V})$, protein bodies $(\mathrm{PB})$, lipid bodies $(\mathrm{LB})$, peroxisomes $(\mathrm{P})$, intracellular spaces (ICS), plasmadesmeta (PD), and cellular membrane (CM) in the control cells (A and B), and $50 \mu \mathrm{M} \mathrm{Pb}(\mathrm{C}$ and D) level of TM-1 and Z-747, respectively. Small arrows $(\rightarrow)$ represent $\mathrm{Pb}$ particles. 
But TM-1 maintained a typical nucleus round shape structure and well-defined nucleoli (Fig. 1 C). Plasmolysis, increase in the number of mitochondria and intercellular spaces; accumulation of $\mathrm{Pb}$ in vacuoles and alongside cell walls was similar in TM-1 and Z-747. The plasma membrane seems more intact in micrographs of TM-1 as compared to Z-747. At $100 \mu \mathrm{M}$, there was greater increase in intercellular spaces, cell wall size, mitochondria, and vacuoles of TM-1 (Figs. 2 E-F). Endoplasmic reticulum (ER) lost its integrity and was found scattered throughout the cytoplasm along with ribosomes. Cell membrane could be seen still attached to cell walls in TM-1 at $100 \mu \mathrm{M} \mathrm{Pb}$. Most of the cells contained more than one vacuole, while others showed just one larger vacuole. On the other side, in Z-747, cell membrane disappearance, deformation of cell wall, disturbance in cell organelles, and disintegration of mitochondria and peroxisomes was found at $100 \mu \mathrm{M}$ (Fig. $2 \mathrm{~F}$ ). The nuclear membrane lost its round structure and nucleoli disappeared or disintegrated and were scattered in the nucleoplasm.

One of the key observations in TM-1 at $300 \mu \mathrm{M} \mathrm{Pb}$ was the presence of nucleoli and nuclear membranes and greater increase in vacuole size, pushing cells organelles toward the cell wall. Pb signals were scattered throughout the cytoplasm (Fig. 2 G). Nuclear membranes vanished in Z-747 and nucleoli, if seen, floated in the cytoplasm. However, the cell wall was still intact and identification of different cell organelles became difficult in Z-747 at this stage (Fig. $2 \mathrm{H}$ ). An increase in the intracellular spaces was a common characteristic found in both varieties. At the highest level of treatment, micrographs of TM-1 cells could be seen with or without clear nucleus, small and large vacuoles filled with cellular debris, and $\mathrm{Pb}$ particles (Fig. $3 \mathrm{I}$ ). The variety Z747 exhibited cell wall deformation at $500 \mu \mathrm{M} \mathrm{Pb}$ (Fig. 3 J). Cell membranes disappeared in many cells and identification of other cell organelles was difficult.

\section{Discussion}

This study reveals the differential response by seeds of two upland cotton varieties under elevated levels of $\mathrm{Pb}$. A decline in germination percentage under $\mathrm{Pb}$ toxicity has been reported in many studies $[9,22]$ mainly due to decline in water content. We observed that seeds of TM-1 absorbed more water than Z-747, hence more germination at all lev-
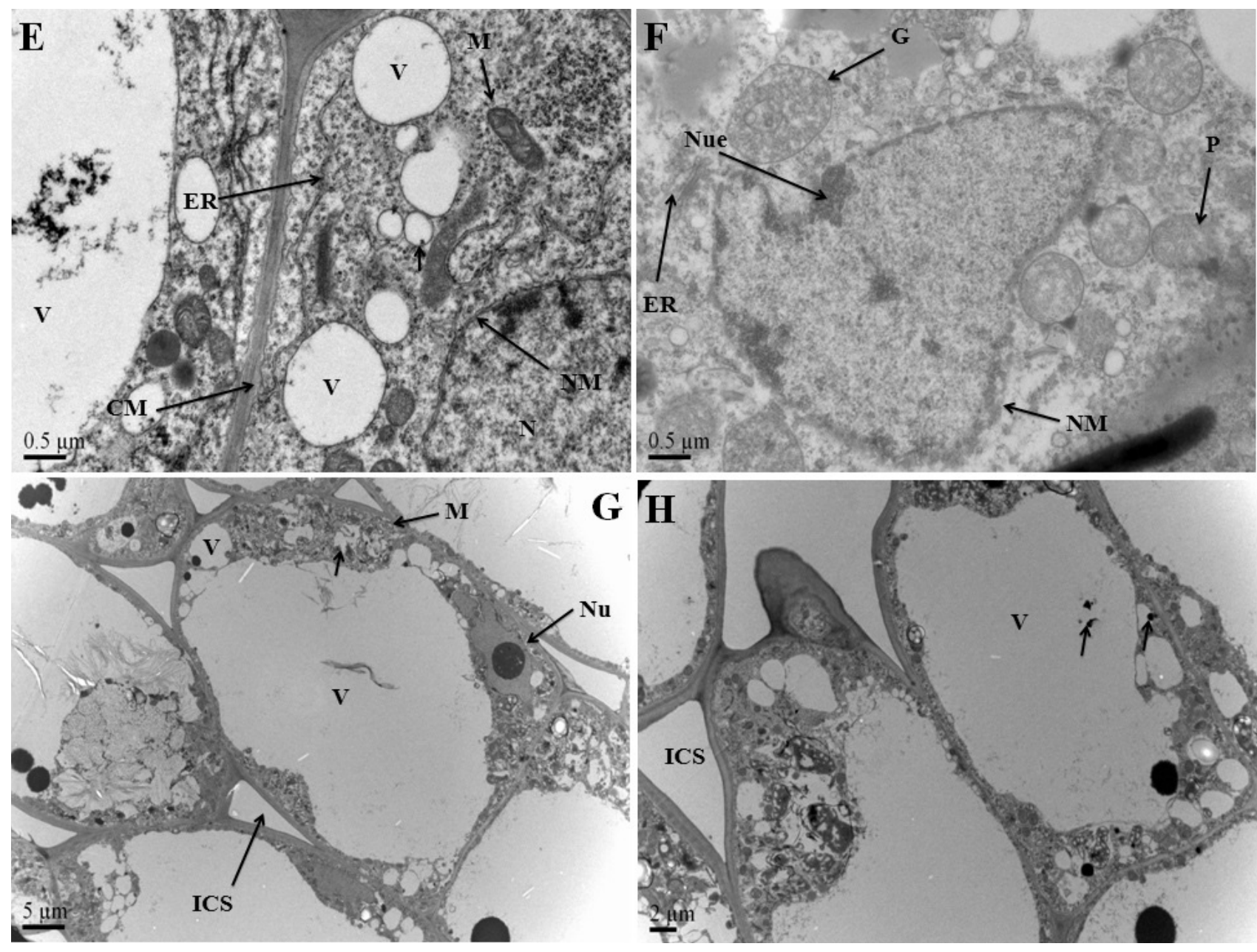

Fig. 2. (E, F) TM-1 and Z-747 at $100 \mu \mathrm{M} \mathrm{Pb}(\mathrm{G}, \mathrm{H}) \mathrm{TM}-1$ and Z-747 at $300 \mu \mathrm{M}$ Pb. Electron micrographs of radical base cells of TM-1 and Z-747 cell organelles, i.e. nucleus $(\mathrm{N})$, nucleolus $(\mathrm{Nu})$, nuclear membrane $(\mathrm{NM})$, cytoplasm $(\mathrm{C})$, mitochondria $(\mathrm{M})$, endoplasmic reticulum (ER), cell wall (CW), protein bodies (PB), intracellular spaces (ICS), and lipid bodies (LB). Small arrows $(\rightarrow)$ indicate $\mathrm{Pb}$. 

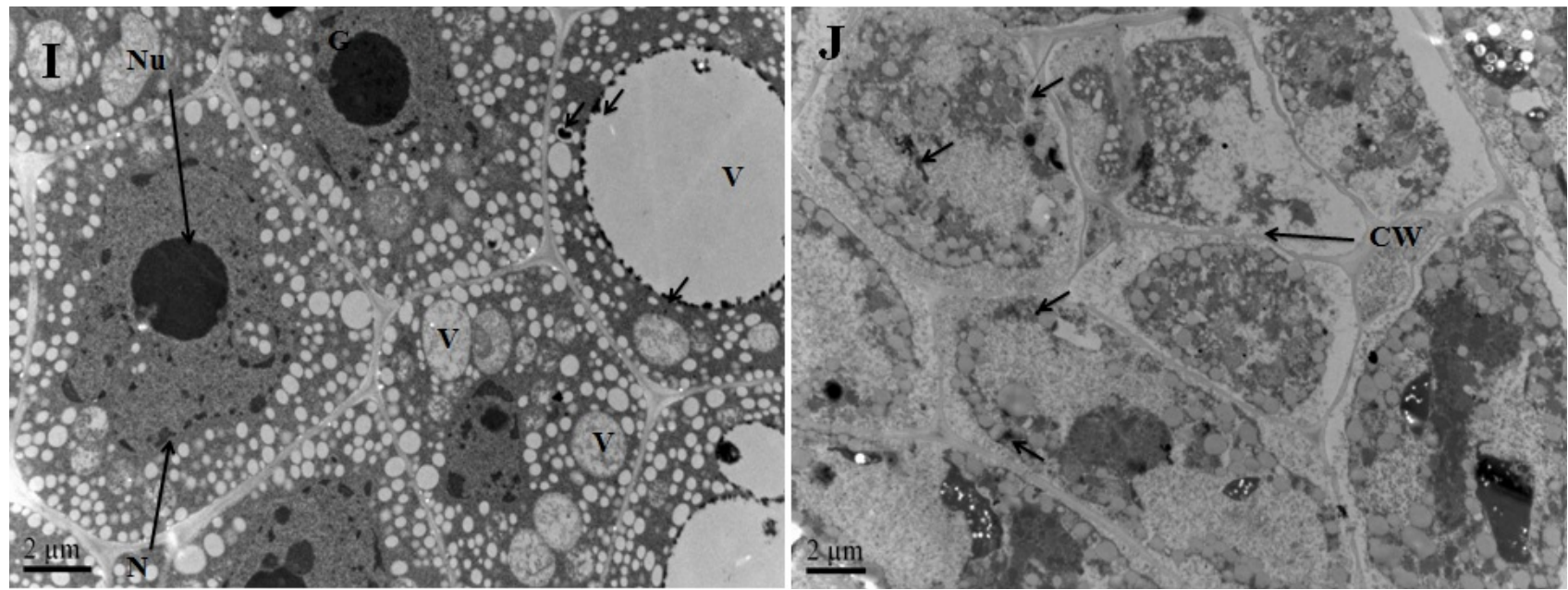

Fig. 3. (I, J) TM-1 and Z-747 at $500 \mu \mathrm{M}$ Pb. Electron micrographs of radical base cells of TM-1and Z-747 showing different cell organelles, i.e. nucleus $(\mathrm{N})$, nucleolus $(\mathrm{Nu})$, nuclear membrane $(\mathrm{NM})$, intercellular spaces (ICS), mitochondria (M), endoplasmic reticulum (ER), ribosomes $(\mathrm{R})$ cell wall $(\mathrm{CW})$, protein bodies $(\mathrm{PB})$, and lipid bodies $(\mathrm{LP})$ at $500 \mu \mathrm{M} \mathrm{Pb}$. Small arrows $(\rightarrow)$ indicate $\mathrm{Pb}$ particles.

els of $\mathrm{Pb}$. Importantly, seeds of TM-1 were bigger in size showing better germination. Several studies have shown a direct relationship between seed size and germination $[23$, 24]. It is known that $\mathrm{Pb}$ causes alterations in the activities of key metabolizing enzymes like amylases, acid invertases, and proteases, thus playing a negative role in exploiting seed reserves for radical emergence and delaying or inhibiting germination [7]. The relative better performance of TM-1 seeds may also be attributed to phytochelatin synthesis, activation of antioxidant enzymes [25], metallothioneins and heat shock proteins [16], and higher flavonoid content [26]. Similarly, phytic acid is also considered a major component of protection against ROS as reported in maize seeds [27]. A stimulatory effect on germination in $\mathrm{TM}-1$ at $50 \mu \mathrm{M} \mathrm{Pb}$ is in comparison to earlier experiments that showed that low concentrations of heavy metals are sensitive to germination and detrimental effects appear only at high concentrations [28].

Considerable attention has been paid to cell viability and programmed cell death (PCD) issues, having an important role in plant growth and development under different environmental stresses [29]. Formazan, an artificial chromogenic dye, allowed assaying viability via reduction of tetrazolium salts (like TTC) by mitochondrial dehydrogenases [30,31]. Incubation time with dehydrogenases to produce pink color is the indicator of viable cells [32]. Plasma membrane is impermeable to macromolecules like TTC, which can penetrate only at higher $\mathrm{Pb}$ concentrations (i.e. 50 and $100 \mu \mathrm{M}$ ), thus disturbing membrane homeostasis. Similar results were found in Avicennia germinas when exposed to heavy metals [33]. A study conducted on germinating wheat seeds indicated a direct relationship between seed vigor (as observed in TM-1) and cell viability [34]. Besides other factors, higher cell viability in TM-1 may be attributed to glutathione (GSH), which provides a stance against ROS by signal transduction and maintaining active protein function [35].
Seed coat permeability defines the influx of the heavy metal ions to cellular matrix [22]. When exposed, $\mathrm{Pb}$ uptake is rapid and accumulation occurs within hours as reported in different species of legumes [36]. Our results showed an increase in Pb uptake in TM-1 and Z-747 at all levels of treatment over control. Similar results were reported in Pluchea sagitallis [37]. $\mathrm{Pb}$ accumulation and sequestration may be attributed to phytochelatins in TM-1 [38].

Ultrastructural observations are valuable tools to study cell organelles and formation of biological molecules [39]. Similarly, deleterious effects of $\mathrm{Pb}$ can be easily evaluated through cell micrographs of desired plant part [10]. From an ultrastructural point of view, our current work is one of very few studies of this kind, at least when it comes to cotton seeds. Typical high resolution morphology of radical base cells could identify differences in both cotton varieties. Micrographs showed cellular change in both varieties but were more prominent in Z-747, even at lowest level of $\mathrm{Pb}$ treatment $(50 \mu \mathrm{M})$. Previous studies report $\mathrm{Pb}$-induced changes in human lymphocytes at very low levels such as 1 $\mu \mathrm{M}$ [40] and in Lemna minor root cells at $15 \mu \mathrm{M}$ [41]. In fact plasma membrane permeability defines $\mathrm{Pb}$ accumulation and subsequent changes. Metal ions get attached to thiol groups of proteins and the hydroxyl part of phospholipids to cause membrane permeability [42]. $\mathrm{Pb}$ also causes chromosomal anomalies as reported in Trigonella foenumgraecum [5] and cell wall modifications due to excessive $\mathrm{H}_{2} \mathrm{O}_{2}$ production [43].

Tolerant behavior by TM-1 may be due to several factors. Mitochondria, a prominent source of ATP, are the signature for cell protection and resistance capabilities at mild stressful conditions [13]. Tolerance in TM-1 may be attributed to mitochondrial organic acids that possibly reduce oxidative damage [44] and phytochelatin formation as reported in aquatic fern [45]. Comparable ultrastructural changes in roots of mined (tolerant) and non-mined (sensitive) ecotypes of Elsholtzia argyi also were reported [11]. 


\section{Conclusions}

The following conclusions can been drawn from the present study:

- $\mathrm{Pb}$ adversely affects germination, water content, cell viability, and morphology of cotton seeds.

- The variety Z-747 showed greater decline in germination percentage, cell viability, and ultrastructural variations due to reduction in water content, imbalance in nutrient uptake, plasma membrane permeability, and higher $\mathrm{Pb}$ accumulation.

- The variety TM-1 proved more tolerant to $\mathrm{Pb}$ stress due to larger seed size, greater water uptake, and controlled permeability to heavy metal ions.

- Sequestration of $\mathrm{Pb}$ in vacuoles and cell walls, phytochelatin synthesis, antioxidant enzymes, and defensive genes expression may have played a significant role in $\mathrm{Pb}$ tolerance of TM-1.

- TM-1 is more tolerant of Pb stress as compared to Z747 and may be considered a potential variety for cultivation on Pb-contaminated soils.

\section{Acknowledgements}

This project was financially supported by the National Natural Science Foundation of China (Project No. 973), the National High Technology Research and Development Program of China, and the Higher Education Commission of Pakistan. We are thankful to the anonymous reviewers for their valuable suggestions and critical comments about this manuscript.

\section{References}

1. BEWLY J.D. Seed germination and dormancy. Plant Cell 9, 1055, 1997.

2. SIDARI M., MALLAMACI C., MUSCOLO A. Drought, salinity and heat differentially affect seed germination of Pinus pinea. J. Forest Res. 13, 326, 2008.

3. ĆURGUZ V. G., RAIČEVIĆ V., VESELINOVIĆ M., TABAKOVIC-TOŠIĆ M., VILOTIĆ D. Influence of heavy metals on seed germination and growth of Picea abies L. Karst. Pol. J. Environ. Stud. 21, (2), 355, 2012.

4. GOPAL R., RIZVI A. H. Excess lead alters growth, metabolism and translocation of certain nutrients in radish. Chemosphere 70, 1539, 2008.

5. CHOUDHARY S., ANSARI M. Y. K., KHAN Z., GUPTA H. Cytotoxic action of lead nitrate on cytomorphology of Trigonella foenum-graecum L. Turk J. Bot. 36, 267, 2012.

6. POURRUT B., SHAHID M., DUMAT C., WINTERTON P., PINELLI E. Lead uptake, toxicity and detoxification in plants. Rev. Environ. Contam. T. 213, 114, 2011.

7. SINGH H. P., KAUR G., BATISH D. R., KOHLI R. K. Lead $(\mathrm{Pb})$-Inhibited radical emergence in Brassica campestris, involves alterations in starch metabolizing enzymes. Biol. Trace Elem. Res. 144, 1295, 2011.

8. YANG Y., WIE X., JIN L. J., WANG W., SHI R. Leadinduced phytotoxicity mechanism involved in seed germination and seedling growth of wheat (Triticum aestivum $\mathrm{L}$.). Ecotox. Environ. Safe. 72, 1982, 2010.
9. KRANNER I., COLVILLE L. Metal and seeds: Biochemical and molecular implications and their significance for seed germination. Environ. Exp. Bot. 72, 93, 2011.

10. KAUR G., SINGH H. P., BATISH D. R., KOHLI R. K. Lead $(\mathrm{Pb})$-induced biochemical and ultrastructural changes in wheat (Triticum aestivum) roots. Protoplasma 21, 255, 2012.

11. ISLAM E., YANG X., LI T., LIU D., JIN X., MENG F. Effects of $\mathrm{Pb}$ on root morphology, physiology and ultrastructure in the two ecotypes of Elsholtzia argyi. J. Hazard. Mater. 147, 806, 2007.

12. NOUET C., MOTTE P., HANIKENNE M. Chloroplastic and mitochondrial metal homeostasis. Trends Plant Sci. 16, 395, 2011.

13. BARTOLI C. G., GOMEZ F., MARTINEZ D. E., GUIAMAT J. J. Mitochondria are the main target for oxidative damage in leaves of wheat (Triticum aestivum L.). J. Exp. Bot. 55, 1663, 2004.

14. ZHENG L., PEER T., SEYBOLD V., MEINDL U. L. Pbinduced ultrastructural alterations and subcellular localization of $\mathrm{Pb}$ in two species of Lespedeza by TEM-coupled electron energy loss spectroscopy. Environ. Exp. Bot. 77, 196, 2012.

15. RASCIO N., IZZO F. N. Heavy metal hyperaccumulating plants: How and why do they do it? And what makes them so interesting? Plant Sci. 180, 169, 2011.

16. HALL J. L. Cellular mechanisms for heavy metal detoxification and tolerance. J. Exp. Bot. 53, 1, 2002.

17. YADAV S. K. Heavy metals toxicity in plants: An overview on the role of glutathione and phytochelatins in heavy metal stress tolerance of plants. S. Afr. J. Bot. 76, 167, 2010.

18. CROCKER W. Role of seed coats in delayed germination. Bot. Gaz. 42, 265, 1906.

19. DAUD M. K., VARIATH M. T., ALI S., NAJEEB U., JAMIL M., HAYAT Y., DAWOOD M., KHAN M. I., ZAFAR M., CHEEMA S. A., TONG X. H., ZHU S. Cadmium-induced ultramorphological and physiological changes in leaves of two transgenic cotton cultivars and their wild relative. J. Hazard. Mater. 168, 614, 2009.

20. DAUD M. K., SUN Y., DAWOOD M., HAYAT Y., VARIATH M. T., WU Y. X., RAZIUDDIN, MISHKAT U., SALAHUDDIN, NAJEEB U., ZHU S. Cadmium-induced functional and ultrastructural alterations in roots of two transgenic cotton cultivars. J. Hazard. Mater. 16, 463, 2009.

21. JIANG D. A. Experimental guide for plant physiology, Chendu Science and Technological University Publisher, Chendu. China, pp. 39, 1999 [In Chinese].

22. WIERZBICKA M., OBIDZIŃSKA J. The effect of lead on seed imbibition and germination in different plant species. Plant Sci. 137, 155, 1998.

23. MÖLKEN T. V., WIENK L. D. J., HOEK P. H. V., KROON H. D. Only seed size matters for germination in different populations of the dimorphic Tragopogon pratensis subsp. Pratensis (Asteraceae). Am. J. Bot. 92, 432, 2005.

24. SADEGHI H., KHAZAEI F., SHEIDAEI S., YARI L. Effect of seed size on seed germination of safflower (Carthamas tinctorius L.). APRN J. Agr. Bio. Sci. 6, 5, 2011.

25. MISHRA S., SRIVASTAVA S., TRIPATHI R. D., KUMAR R., SETH C. S., GUPTA D. K. Lead detoxification by coontail (Ceratophyllum demersum L.) involves induction of phytochelatins and antioxidant system in response to its accumulation. Chemosphere 65, 1027, 2006.

26. HORBOWICZ M., DĘBSKI H., WICZKOWSKI W., SZAWARA-NOWAK D., KOCZKODAJ D., MITRUS J., SYTYKIEWICZ H. The impact of short-term exposure to $\mathrm{Pb}$ and $\mathrm{Cd}$ flavonoid composition and seedling growth of 
common buckwheat cultivars. Pol. J. Environ. Stud. 22, (6), 1723, 2013.

27. DURIA E., GALLESCHI L., CALUCCI L., PINZINO C., PILU R., CASSANI E., NIELSEN E. Phytic acid prevents oxidative damage in seeds: evidence from a maize (Zea mays L.) low phytic acid mutant. J. Exp. Bot. 60, 967, 2009.

28. CHUGH L. K., SAWHNEY S. K. Effect of cadmium on germination, amylases and rate of respiration of germination pea seeds. Environ. Pollut. 92, 1, 1996.

29. DORN W. G. V., BEERS E. P., DANGL J. L., FRANKLINTONG V. E., GALLOIS P., HARA-NISHIMURA I., JONES A.M., KAWAI-YAMADA M., LAM E., MUNDY J., MUR L. A. J., PETERSEN M., SMERTENKO A., TALIANSKY M., VAN BREUSEGEM F., WOLPERT T., WOLTERING E., ZHIVOTOVSKY B., BOZHKOV P. V. Morphological classification of plant cell deaths. Cell Death Differ. 18, 1241, 2011.

30. JOSLIN J. D., HENDERSON G. S. The determination of percentages of living tissue in woody fine root samples using triphenyltetrazolium chloride. Forest Sci. 30, 965, 1984.

31. MEREWITZ E. B., GIANFAGNA T., HUANG B. Photosynthesis, water use and root viability under water stress as affected by expression of SAG12-ipt controlling cytokinin synthesis in Agrostis stolonifera. J. Exp. Bot. 62, 383, 2011.

32. MEDRANO R. M. E. G., HAM M. D. L. M. Analysis of elicitor-induced cell viability changes in Lycopersicum esculentum Mill. suspension culture by different methods. In Vitro Cell Dev-Pl. 39, 236, 2003.

33. DANIEL G. M., ANDRIANA Q. M., ROSA E., GRACIA M., ONECIMO G. J., OMAR Z. P. Cell viability and leakage of electrolytes in Avicennia germinans exposed to heavy metals. Z. Naturforsch C 64, 391, 2009.

34. STANDARD S. A., PERRET D., BRAY C. M. Nucleotide levels and loss of vigor and viability in germinating wheat embryos. J. Exp. Bot. 34, 1047, 1983.

35. FOYER C. H., NOCTOR G. Oxidant and antioxidant signaling in plants: a re-evaluation of the concept of oxidative stress in a physiological context. Plant Cell Environ. 28, 1056, 2005.
36. PIECHALAK A., TOMASZEWSKA B., BARALKIEWICZ D., MALECKA A. Accumulation and detoxification of lead ions in legumes. Phytochemistry 60, 153, 2002.

37. ROSSATO L. V., NICOLOSO F. T., CARGNELLUTI D., TABALDI L. A., ANTES F. G., DRESSLER V. L., MORCSH V.M., SCHETINGER M. R. Effect of Lead on growth, $\mathrm{Pb}$ accumulation and physiological responses of Pluchea sagitallis. Ecotoxicology 2, 111, 2012.

38. COBBETT C. S. Phytochelatins and their roles in heavy metal detoxification. Plant Physiol. 123, 825, 2000.

39. COLONY A. J., JOENSUU J. J., MENASSA R., BRANDLE J. E. Induction of protein body formation in plant leaves by elastin-like polypeptide fusions. BMC Biol. doi: 10.1186/1741-7007-7-48, 7, 48, 2009.

40. WOŹNIAK K., BLASIAK J. In vitro genotoxicity of lead acetate: induction of single and double strand breaks and DNA-protein cross-links. Mutat. Res. 535, 127, 2003.

41. SAMARDAKIEWICZ S., WOZNY A. Cell division in Lemna minor roots treated with lead. Aquat. Bot. 83, 289, 2005.

42. RUSSAK M. J., KABALA K., BURZYŃSKI M., KLOBUS G. Response of plasma membrane $\mathrm{H}^{+}$-ATPase to heavy metal stress in Cucumis sativus roots. J. Exp. Bot. 59, 3721, 2008.

43. MARCO A. D., KALLIOPI A. R. A. The complexity of enzymic control of hydrogen peroxide concentration may affect the regeneration potential of plant protoplast. Plant Physiol. 110, 137, 1996.

44. KEUNEN E., REMANS T., BOHLER S., VANGRONSVELD J., CUYPERS A. Metal-induced oxidative stress and plant mitochondria. Int. J. Mol. Sci. 12, 6894, 2011.

45. ESTRELLA G. N., MENDOZA C. D, MORENO S. R., GONZALEZ M. D., ZAPATA O. P., MARTINEZ H. A., SANTAMARIA J. M. The Pb-hyperaccumulator aquatic fern Salvinia minima Baker, responds to $\mathrm{Pb}^{2+}$ by increasing phytochelatins via changes in SmPCS expression and in phytochelatin synthase activity. Aquat. Toxicol. 91, 320, 2009. 